\title{
Soil Quality Response to Long-Term Nutrients and Management Practice to Potato Production in Ultisols of Subtropical China
}

\author{
Odunze A. C. (Corresponding author) \\ Key Laboratory of Agro-ecological Processes in Subtropical Region \\ Institute of Subtropical Agriculture, Chinese Academy of Sciences, Changsha 410125, China \\ $\&$ \\ Department of Soil Science/IAR, Ahmadu Bello University, P M B 1044, Zaria, Nigeria \\ Tel: 234-803-572-2052Ｅ-mail: odunzeac@gmail.com, odunzeac@yahoo.com \\ Jinshui Wu (Corresponding author) \\ Key Laboratory of Agro-ecological Processes in Subtropical Region \\ Institute of Subtropical Agriculture, Chinese Academy of Sciences, Changsha 410125, China \\ E-mail: jswu@isa.ac.cn \\ Shoulong Liu \\ Key Laboratory of Agro-ecological Processes in Subtropical Region \\ Institute of Subtropical Agriculture, Chinese Academy of Sciences, Changsha 410125, China \\ E-mail: along@isa.ac.cn \\ Hanhua Zhu \\ Key Laboratory of Agro-ecological Processes in Subtropical Region \\ Institute of Subtropical Agriculture, Chinese Academy of Sciences, Changsha 410125, China \\ E-mail: hhzhu@126.com
}

Tida Ge

Key Laboratory of Agro-ecological Processes in Subtropical Region

Institute of Subtropical Agriculture, Chinese Academy of Sciences, Changsha 410125, China

E-mail: gtd@isa.ac.cn

Yi Wang \& Qiao Luo

Key Laboratory of Agro-ecological Processes in Subtropical Region

Institute of Subtropical Agriculture, Chinese Academy of Sciences, Changsha 410125, China

Received: December 13, 2011

Accepted: January 20, 2012 Published: March 1, 2012

doi:10.5539/enrr.v2n1p129

URL: http://dx.doi.org/10.5539/enrr.v2n1p129

\begin{abstract}
Development of sustainable agricultural system require cognizance of soil quality status, extent and impact of degradation processes and land use management strategy in practice. Response of soils to management and inputs are important considerations that depend on soil quality and was therefore evaluated in this study for Ultisols in subtropical China. Changes in soil quality were assessed by measuring appropriate indicators from a
\end{abstract}


long-term experiment at the Taoyuan Station, Hunan province, China from 2000 to 2009. Data obtained were analyzed using the SAS statistical package for ANOVA and means were separated with DNMRT, matched graphically to delineate threshold limits for a minimum threshold data set. Results show that the soils responded positively with Sweet potato-rape/NP+straw treatment $\left(7.18 \mathrm{~g} \mathrm{~kg}^{-1}\right)$ contributing significantly $(\mathrm{P}<0.05)$ higher total carbon and least total carbon was contributed from Sweet potato-rape/nil fertilizer and Fallow/nil fertilizer application treatments. Highest total nitrogen was contributed by Sweet potato-rape/NP+ straw $\left(0.882 \mathrm{~g} \mathrm{~kg} \mathrm{~g}^{-1}\right)$ and was significantly $(\mathrm{P}<0.05)$ higher than each of the other treatments. Sweet potato-rape/NPK+stalk treatment also resulted in significantly higher biomass carbon (132.66 mg kg $\left.\mathrm{g}^{-1}\right)$ to be better biomass carbon contributors than the other treatments. Biomass nitrogen contributed by Sweet potato-rape/NPK+stalk $\left(23.96 \mathrm{mg} \mathrm{kg}^{-1}\right)$ was also significantly higher, to be preferred over Sweet potato-rape/NPK $\left(18.34 \mathrm{mg} \mathrm{kg}^{-1}\right)$, Sweet potato-rape/nil fertilizer $\left(16.36 \mathrm{mg} \mathrm{kg}^{-1}\right)$ or Fallow/nil fertilizer $\left(14.92 \mathrm{mgkg}^{-1}\right)$ in contributing nitrogen into the Ultisols. This study also show that treatments with stalk amendments resulted in 3.6 to $5.7 \%$ biomass carbon and 15.8 to $23.5 \%$ biomass nitrogen increase over Sweet potato-rape/NPK. Increasing trends of biomass carbon, nitrogen and phosphorus in the Ultisols were attributed to organic matter inputs as compliment fertilizer materials. Percent decline in potato yields were as high as $65.57 \%$ of 2007 yield value and require that further investigation be conducted to ascertain cause of this decline and forestall future yield depressions. Threshold limits for selected minimum data set for the subtropical China region Ultisols on sweet potato production was produced to enhance future soil quality monitoring in support of sustainable crop production and national food security.

Keywords: Soil Quality, Land Use Management, Threshold limits, Sustainable Agriculture, Soil Health

\section{Introduction}

Degradation of soil as a consequence of land use poses a threat to sustainable agriculture, resulting in the need for appropriate soil protection strategy and policy. Development of such a strategy and policy require cognizance of the soil quality status, extent and impact of soil degradation processes and land use management strategy in practice. Sustainability of agricultural systems has become an important issue in developing countries, including China. Over-exploitation of soils over many decades has resulted in exhaustion of intensive agricultural production systems and steadily declining productivity has been noticed in long-term experiments in Asia (Reginald et al., 2007). Many of the issues of sustainability are related to soil quality and its assessment. The direction of change with time is therefore a primary indicator of whether or not agriculture is sustainable (Karlen et al., 1997). The response of soils to management and inputs also are important considerations and depends on soil quality. It is therefore important to identify the soil characteristics responsible for changes in the subtropical China region Ultisols' quality, which may eventually be considered as soil quality indicators for assessing agricultural sustainability on the soils.

Changes in soil quality can be assessed by measuring appropriate indicators and comparing them with desired values (critical limits or threshold level), at different time intervals, for a specific use in a selected agro-ecosystem. Such a monitoring system will provide information on the effectiveness of the selected farming system, land use practices, technologies and policies (Arshad \& Martin, 2002). However, Doran and Parkin, (1994) defined soil quality as the "capacity of the soil to function within ecosystem boundaries to sustain biological productivity, maintain environmental quality, and promote plant and animal health". Soil quality indicators refer to measurable soil attributes that influence the capacity of soil to perform crop production or environmental functions. Attributes that are most sensitive to management are most desirable as indicators (Arshad \& Martin, 2002). Such indicators chosen should be a reflection of producer success and/or natural resource conservation. They should also be relatively easy to measure and simple to interpret. Examples of indicators meeting these criteria include crop yield, profit, risk of crop failure, soil organic matter content, soil depth, percent soil cover, leachable salts (especially $\mathrm{NO}_{3}-\mathrm{N}$ ), and energy use (Liebig et al., 1996). A minimum data set helps to identify locally relevant soil indicators, evaluate the link between selected indicators and significant soil and plant properties (Arshad and Martin, 2002) and provide a comprehensive understanding of soil attributes evaluated. More importantly they serve as a useful tool for screening the condition, quality, and health of soil (Doran et al., 1996; Larson \& Pierce, 1994; Doran \& Parkin, 1994). For smallholder farmers these tools need to be simple measures of soil health and soil quality such as consistency, color and workability (Murage et al., 2000; Bastida et al., 2008; Reginald et al., 2007) and crop yield. For extension and policy personnel, they provide basic information needed to arrive at management decisions (Barrios et al., 2006). For researchers, there is need to conduct sufficiently detailed tests while controlling for variation in order to develop meaningful assessments of soil status, often expressed as an index of soil quality (Kang et al., 2005). A minimum data set selected for assessing soil quality in this study include soil $\mathrm{pH}$, total carbon, total nitrogen, total phosphorus, microbial carbon, microbial nitrogen, microbial phosphorus and yield of potato, as these would 
satisfy the farmer, extension workers and policy personnel and research scientists' needs for interventions on soil conditions in Ultisols of subtropical China region.

Sweet potato is a thriving production activity in the subtropical region of China grown under varying land use management strategies. The present study therefore aims at evaluating Ultisols quality under a long-term (2000-2009) potato production and Potato yield trends over the period in subtropical China region.

\section{Materials and Methods}

The trials on Sweet potato production with and without fertilizer sources were conducted on the long-term experiment site at Taoyuan Station, Hunan province, China from 2000 to 2009. The experiment was established in 2000 in Taoyuan County, at a hilly site $\left(111^{\circ} 31^{\prime} \mathrm{E}, 29^{\circ} 14^{\prime} \mathrm{N}\right)$ in the middle of subtropical region of China. The site has a gradient of $8^{\circ}$, a mean elevation of $106 \mathrm{~m}$, annual temperature of $16.8^{\circ} \mathrm{C}$ and annual rainfall of 1,330 $\mathrm{mm}$. Soil at the experimental site was a clay loam classified as Ultisol (USDA Soil Taxonomy, 1998) developed from Quaternary red earth.

The trial treatments were
i) Fallow/nil fertilizer
ii) Sweet potato-rape/nil fertilizer
iii) Sweet potato-rape/NPK
iv) Sweet potato-rape/NP+straw
v) Peanut-broadbean/NP+straw
vi) Maize-barley/NK+marsh residue
vii) Maize-Vegetable/NK+marsh residue

Each treatment was replicated six times in the slope land areas on plots of $21 \mathrm{~m}^{2}$ area $(3 \mathrm{~m} \times 7 \mathrm{~m})$. The applied rate of Straw was 12.7 tha $^{-1} \mathrm{yr}^{-1}$, marsh residue was 10.0 tha $^{-1} \mathrm{yr}^{-1}$ and fertilizer rates were $224 \mathrm{KgNha}^{-1} \mathrm{yr}^{-1}, 52$ $\mathrm{KgPha}^{-1} \mathrm{yr}^{-1}$ and $174 \mathrm{KgKha}^{-1} \mathrm{yr}^{-1}$. Sweet potato yields were taken at fresh weight of tuber condition. Soil samples were collected at $0-20 \mathrm{~cm}$ depths using soil auger from each replicate, air dried and sieved through $2.0 \mathrm{~mm}$ sieve mesh to obtain sub samples for analysis. Soil samples were analyzed for total carbon, nitrogen, phosphorus and $\mathrm{pH}$, microbial carbon, nitrogen and phosphorus.

Organic carbon concentration was measured by the combustion method using an automated $\mathrm{C} / \mathrm{N}$ analyzer (Vario MAX CN, Elemental Co., Germany) while total nitrogen was by the Kjeldahl method of ISSCAS (1978). Available Phosphorus was by the Olsen-P extracted in a pH 8.5 solution of $0.5 \mathrm{~mol} \mathrm{dm}^{-1}$ sodium-bicarbonate $\left(\mathrm{NaHCO}_{3}\right)$ and determined using ultraviolet spectrophotometry (UV-8500). Microbial carbon, nitrogen and phosphorus levels were determined using the chloroform-fumigation-extraction method (Jenkinson \& Powlson, 1976; Vance et al., 1987; Brookes et al., 1982) and adopting the conversion factors 0.45 (Wu et al., 1990), 0.45 (Brookes et al., 1985), and 0.29 (Wu et al., 2000) respectively for the C, N and P. Extractable N and Olson P was taken from values obtained from the non fumigated soil samples.

Data obtained were subjected to statistical analysis using the SAS analysis of variance package and mean differences were separated using Duncan's new multiple range tests (DNMRT) at 5\% levels of significance. Treatment means were matched graphically to obtain threshold limits for nutrients and potato tuber yield for measuring soil quality trends to guide management decisions in support of sustainable potato production on Ultisols in subtropical China region.

\section{Results and Discussion}

\subsection{Total carbon, total nitrogen and total phosphorus contents}

Table 1 presents data on total carbon, total nitrogen and total phosphorus content of soils under the varying treatments and shows that Sweet potato-rape/NP+straw treatment $\left(7.18 \mathrm{~g} \mathrm{~kg}^{-1}\right)$ responded well in contributing significantly $(\mathrm{P}<0.05)$ higher total carbon, followed by Peanut-broadbean/NP+straw $\left(6.81 \mathrm{~g} \mathrm{~kg}^{-1}\right)$ that was significantly higher than the other treatments (Table 1 ). However, maize-vegetable/ $\mathrm{NK}+$ marsh residue was significantly superior $\left(6.66 \mathrm{~g} \mathrm{~kg}^{-1}\right)$ to maize-barley/NK+marsh residue $\left(6.53 \mathrm{~g} \mathrm{~kg}^{-1}\right)$ and Sweet potato-rape/NPK $\left(6.52 \mathrm{~g} \mathrm{~kg}^{-1}\right)$; both of which were not statistically different. The least total carbon was contributed from Sweet potato-rape/nil fertilizer and Fallow/nil fertilizer application treatments (Table 1)

Table 1 also show that highest total nitrogen was contributed by Sweet potato-rape/NP+ straw $\left(0.882 \mathrm{~g} \mathrm{~kg}^{-1}\right)$ and is significantly $(\mathrm{P}<0.05)$ different with each of the other treatments. However, Peanut-broadbean $/ \mathrm{NP}+$ straw had 
significantly higher total nitrogen content $\left(0.856 \mathrm{~g} \mathrm{~kg}^{-1}\right)$ than Maize-barley/NK+marsh residue $\left(0.844 \mathrm{~g} \mathrm{~kg}^{-1}\right)$ and Maize-Vegetable/NK+marsh residue $\left(0.834 \mathrm{~g} \mathrm{~kg}^{-1}\right)$. Perhaps, because peanut and broadbeans are legumes their root nodule rhizobia may have contributed extra nitrogen beyond that contributed by the non legume based treatments. The organic matter compliment treatments contributed significantly higher total nitrogen than Sweet potato-rape/NPK $\left(0.814 \mathrm{~g} \mathrm{~kg}^{-1}\right)$, Sweet potato-rape/nil fertilizer $\left(0.715 \mathrm{~g} \mathrm{~kg}^{-1}\right)$ and Fallow/nil fertilizer treatments that lack organic matter. This suggests that inclusion of organic matter in the forms of straw or residues enhanced total carbon and nitrogen contributions of the treatments to improve quality of the Ultisolsl in support of Wu (2011), Tida et al. (2011) and Hanhua et al. (2010). Total phosphorus content of soils under Maize-vegetable/NK+marsh residue $\left(0.398 \quad \mathrm{mg} \quad \mathrm{kg}^{-1}\right)$, Sweet potato-rape/NPK $\left(\begin{array}{lllll}0.380 & \mathrm{mg} & \mathrm{kg}^{-1}\end{array}\right)$, Maize-barley/NK+marsh residue $\left(0.375 \mathrm{mg} \mathrm{kg}^{-1}\right)$, Peanut-broadbean/NP+straw $\left(0.375 \mathrm{mg} \mathrm{kg}^{-1}\right)$ and Sweet potato-rape/NP+straw $\left(0.351 \mathrm{mg} \mathrm{kg}^{-1}\right)$ were not significantly different between treatments, but differed significantly with treatments that lacked fertilizer inputs (Table 1). Soil $\mathrm{pH}$ values were generally strong to strongly acid, except that Sweet potato-rape/NP+straw (pH 5.126) significantly moderated soil acidity better than the other treatments (Table 1). The highest acid conditions were obtained under Sweet potato-rape/NPK (pH 4.974); perhaps indicating the potential for these Ultisols to be acid degraded under continued use of sole inorganic fertilizers for crop production.

\subsection{Microbial carbon, microbial nitrogen and microbial phosphorus}

Table 2 presents data on biomass carbon, nitrogen and phosphorus contents of the soils and shows that Sweet potato-rape/NPK+stalk treatment resulted in significantly higher biomass carbon $\left(132.66 \mathrm{mg} \mathrm{kg}^{-1}\right)$ and was closely followed by Earthnut-broadbean/NPK+stalk $\left(129.81 \mathrm{mg} \mathrm{kg}^{-1}\right)$ to be better biomass carbon contributors than the other treatments (Table 3). Biomass nitrogen contributed by Sweet potato-rape/NPK+stalk (23.96 mg $\left.\mathrm{kg}^{-1}\right)$ was also significantly higher, followed by Earthnut-broadbean/NPK+stalk $\left(21.76 \mathrm{mg} \mathrm{kg}^{-1}\right)$ to be preferred over Sweet potato-rape/NPK (18.34 mg kg-1), Sweet potato-rape/nil fertilizer $\left(16.36 \mathrm{mg} \mathrm{kg}^{-1}\right)$ or Fallow/nil fertilizer $\left(14.92 \mathrm{mg} \mathrm{kg}^{-1}\right)$ in contributing nitrogen into the soil. This finding corroborates findings by Hanhua et al. (2010) in similar study that the content of microbial carbon, nitrogen and phosphorus increased by $18-43 \%$ compared with values when chemical fertilizers (NPK) were applied alone. This study also show that treatments with stalk amendments resulted in 3.6 to $5.7 \%$ biomass carbon and 15.8 to $23.5 \%$ biomass nitrogen increase over Sweet potato-rape/NPK, to encourage inclusion of organic matter as soil amendments in Slope lands of subtropical China region Ultisols for cultivation activities. Between Sweet potato-rape/NPK $\left(6.45 \mathrm{mg} \mathrm{kg}^{-1}\right)$, Sweet potato-rape/NPK+stalk $\left(7.35 \mathrm{mg} \mathrm{kg}^{-1}\right)$ and Earthnut-broadbean/NPK+stalk $\left(7.38 \mathrm{mg} \mathrm{kg}^{-1}\right)$ treatments, there were no significant differences in there biomass $\mathrm{P}$ contributions, but each was significantly higher than Sweet potato-rape/nil fertilizer $\left(4.97 \mathrm{mg} \mathrm{kg}^{-1}\right)$ and Fallow/nil fertilizer (Table 2) treatments (4.98 $\left.\mathrm{mg} \mathrm{kg}^{-1}\right)$.

\subsection{Potato fresh tuber yield 2000-2009}

Table 3 presents potato yield results that indicate highest tuber yield in $2000\left(4.38\right.$ tha $\left.^{-1}\right)$ and yearly decline to as low as 1.53 tha $^{-1}$ in 2007 and 1.82 tha $^{-1}$ in 2008. Percent decrease in potato yields were as high as $65.57 \%$ of 2007 yield value and require that further investigation be conducted to ascertain the cause for this decline in production of potato. However, biomass carbon and nitrogen of soils in the potato field falls within the low threshold limit for upland areas earlier determined for Ultisols on the Uplands of subtropical China region. This could in part account for the decline in potato yield but may not be for the trend in reduction with years. Also, soil $\mathrm{pH}$ in the potato fields was in the strongly acid limits and could part contribute to decrease in potato tuber yield. Increased incorporation of organic matter (straw, stalks etc) into soils under Sweet potato production in the slope lands would improve microbial biomass carbon, nitrogen and phosphorus that would be more readily available for crop roots uptake and improve soil quality and yield of potato crops subsequently.

\subsection{Threshold limits determination for the potato slope land field}

Figures 1 to 7 present graphical views of treatment means of soil $\mathrm{pH}$, total carbon, nitrogen and phosphorus, icrobial carbon, nitrogen and phosphorus and yields of potato in Ultisols for subtropical China slope lands potato field matched to delineate threshold boundaries for high, medium and low levels detailed in Table 4. Determined Potato field threshold limits were compared with threshold limit values for Upland Ultisols in subtropical China zone and potato field values were in the low limits for Soil $\mathrm{pH}$, biomass carbon, nitrogen and phosphorus. Upgrading the levels of microbial biomass carbon, nitrogen and phosphorus in the Ultisols to at least that in the Uplands would improve quality capacity of the soils for sustainable agricultural productivity.

\section{Conclusion}

The study revealed that Sweet potato-rape/NP+straw treatment $\left(7.18 \mathrm{~g} \mathrm{~kg}^{-1}\right)$ contributed significantly $(\mathrm{P}<0.05)$ higher total carbon, followed by Peanut-broadbean/NP+straw $\left(6.81 \mathrm{~g} \mathrm{~kg}^{-1}\right)$ that was significantly higher than the 
other treatments and least total carbon was contributed from Sweet potato-rape/nil fertilizer and Fallow/nil fertilizer application treatments in the Ultisols. Also, highest total nitrogen was contributed by Sweet potato-rape/NP+ straw $\left(0.882 \mathrm{~g} \mathrm{~kg}^{-1}\right)$ and was significantly $(\mathrm{P}<0.05)$ higher than each of the other treatments. The organic matter complimented treatments are therefore inferred to have contributed significantly higher total nitrogen and carbon than Sweet potato-rape/NPK $\left(0.814 \mathrm{~g} \mathrm{~kg}^{-1}\right)$, Sweet potato-rape/nil fertilizer $\left(0.715 \mathrm{~g} \mathrm{~kg}^{-1}\right)$ and Fallow/nil fertilizer treatments that lack organic matter input. This supports the inclusion of organic matter in the forms of straw or residues as fertilizer inputs to enhance total carbon and nitrogen accretions in the subtropical China Ultisols.

Sweet potato-rape/NPK+stalk treatment resulted in significantly higher biomass carbon $\left(132.66 \mathrm{mg} \mathrm{kg}^{-1}\right)$ and was closely followed by Earthnut-broadbean/NPK+stalk $\left(129.81 \mathrm{mg} \mathrm{kg}^{-1}\right)$ to be better biomass carbon contributors than the other treatments. Biomass nitrogen contributed by Sweet potato-rape/NPK+stalk $(23.96 \mathrm{mg}$ $\left.\mathrm{kg}^{-1}\right)$ was also significantly higher, followed by Earthnut-broadbean/NPK+stalk $\left(21.76 \mathrm{mg} \mathrm{kg}^{-1}\right)$ to be preferred over Sweet potato-rape/NPK $\left(18.34 \mathrm{mg} \mathrm{kg}^{-1}\right)$, Sweet potato-rape/nil fertilizer $\left(16.36 \mathrm{mg} \mathrm{kg}^{-1}\right)$ or Fallow/nil fertilizer $\left(14.92 \mathrm{mg} \mathrm{kg}^{-1}\right)$ in contributing nitrogen into the soil. This study also show that treatments with stalk amendments resulted in 3.6 to $5.7 \%$ biomass carbon and 15.8 to $23.5 \%$ biomass nitrogen increase over Sweet potato-rape/NPK, to encourage inclusion of organic matter as soil amendments in the subtropical China Ultisols' cultivation activities. The increasing trends of biomass carbon, nitrogen and phosphorus in the soils are attributed to organic matter inputs as compliment fertilizer materials and would improve the quality of these Ultisols for sustainable crop production.

However, percent decline in potato yields were as high as $65.57 \%$ of 2007 yield value and require that further investigation be conducted to ascertain the cause of this decline in production and to mitigate future yield depressions on the soil.

Threshold limits for selected minimum data set for the subtropical China region Ultisols on sweet potato production was produced to enhance future soil quality monitoring in support of sustainable crop production and national food security on the soil order.

\section{Acknowledgements}

The authors appreciate authorities of the Institute of Subtropical Agriculture, The Key Laboratory of Agro-ecological Processes in Subtropical Regions, The Chinese Academy of Sciences, China for availing Senior Visiting Scientist position to Odunze AC and providing data set for the study, as well as TWAS-UNESCO for offering a Research Fellowship to Odunze AC to accomplish this work. Also, the authors appreciate immensely authorities of Ahmadu Bello University Zaria, Nigeria for authorizing the mission to China by A. C. Odunze.

\section{References}

Arshad, M. A., \& Martin, S. (2002). Identifying critical limits for soil quality indicators in agro-ecosystems. Agriculture, Ecosystems \& Environment, 88(2), 153-160. http://dx.doi.org/10.1016/S0167-8809(01)00252-3

Barrios, E., \& Trejo, M.T. (2003). Implications of local soil knowledge for integrated soil fertility management in Latin America. Geoderma, 111, 217-231. http://dx.doi.org/10.1016/S0016-7061(02)00265-3

Bastida, F., Zsolnay, A., Hernandez, T., \& Garcia, C. (2008). Past, Present and Future of Soil Quality Indices: A Biological Perspective. Geoderma, 147(3-4), 159-171. http://dx.doi.org/10.1016/j.geoderma.2008.08.007

Brookes, P. C., Powlson, D. S., \& Jenkinson, D. S. (1982). Measurement of Microbial Biomass Phosphorus in Soils. Soil Biol Biochem, 14, 319-329. http://dx.doi.org/10.1016/0038-0717(82)90001-3

Doran, J.W., \& Parkin, T.B. (1994). Defining and assessing soil quality. In: Doran, J.W., Coleman, D.C., Bezdicek, D.F., Stewart, B.A. (Eds.), Defining Soil Quality for a Sustainable Environment. Soil Science Society of America Special Publication, vol. 35. Soil Science Society of America, Madison, Wisconsin, pp. 3-21.

Doran, J.W., Sarrantonio, M., \& Liebig, M. (1996). Soil health and sustainability. In: Sparks, D.L. (Ed.), advances in Agronomy, Vol. 56. Academic Press, San Diego, pp. 1-54.

Institute of Soil Science, Chinese Academy of Sciences (ISSCAS). (1978). Soil Physical and Chemical Analysis. Shanghai Sciences and Technology Press, Shanghai, pp 62,132

Jenkinson, D. S., \& Powlson, D. S. (1976). The effect of biocidal treatments on metabolism in soils: A method for measuring biomass. Soil Biol Biochem, 8, 209-213. http://dx.doi.org/10.1016/0038-0717(76)90005-5 
Kang, G.S., Beri, V., Sidhu, B.S., \& Rupela, O.P. (2005). A new index to assess soil quality and sustainability of wheat-based cropping systems. Biology and Fertility of Soils, 41, 389-398. http://dx.doi.org/10.1007/s00374-005-0857-4

Karlen, D. L., Mausbach, M. J., Doran, J. W., Cline, R. G., Harris, R. F., \& Schuman, G. E. (1997). Soil quality: a concept, definition, and framework for evaluation. Soil Science Society of America Journal, 61, 4-10. http://dx.doi.org/10.2136/sssaj1997.03615995006100010001x

Larson, W. E., \& Pierce, F. J. (1994). The dynamics of soil quality as a measure of sustainable mangement. Pages 37-51 in J. W. Doran, D. C. Coleman, D. F. Bezdicek and B. A. Stewart, eds. Defining soil quality for a sustainable environment. SSSA- Special Publication 35. Soil Science Society of America, Madison, WI, USA. Reginald et al. 2007

Liebig, M.A., Doran, J.W., \& Gardner, J.C. (1996). Evaluation of a field test kit for measuring selected soil quality indicators. Agronomy Journal, $88, \quad 683-686 . \quad \mathrm{http}: / / \mathrm{dx}$. doi.org/10.2134/agronj1996.00021962008800040030x

Murage E.W., Karanja N.K., Smithson P.C., \& Woomer P.L. (2000). Diagnostic indicators of soil quality in productive and non-productive smallholders fields of Kenya's Central highlands. Agriculture, Ecosystems and Environment, 79, 1-8. http://dx.doi.org/10.1016/S0167-8809(99)00142-5

Reginald Ebhin Masto, Prmod K. Chhonka, Dhyan Singh, \& Ashokk Patra. (2007). Soil quality response to long-term nutrient and crop management on a semi-arid Inceptisol. Agriculture, Ecosystems \& Environment, 118(1-4), 130-142(Jan 2007)

Tida, Ge, Nie, San'an, Wu, Jinshui, Shen, Jianlin, Xiao, He'ai, Tong, Chengli, Huang, Danfeng, Hong, Yun, \& KaoIwasaki. (2011). Chemical properties, microbial biomass and activity differ between soils of organic and conventional horticultural systems under greenhouse and open field management: a case study. Journal of Soil Sediments, 11, 25-36. http://dx.doi.org/10.1007/s11368-010-0293-4

United States Department of Agriculture. (USDA). Natural Resources Conservation Services 1998. Keys to Soil Taxonomy. $8^{\text {th }}$ Edition. P 326.

Vance, E.D., Brookes, P. C., \& Jenkinson, D. S. (1987). An extraction method for measuring soil microbial biomass C. Soil Biol Biochem, 19, 703-707. http://dx.doi.org/10.1016/0038-0717(87)90052-6

Wu. J. (2011). Carbon accumulation in paddy ecosystems in subtropical China: evidence from landscape studies. European Journal of Soil Science February, 62, 29-34. http://dx.doi.org/10.1111/j.1365-2389.2010.01325.x

Wu, Jinshui, Huang, Min, Xiao, He-Ai, Su, Yi-Rong, Tong, Cheng-Li, Huang, Dao-You, \& J. Keith Sters. (2007). Dynamics in microbial immobilization and transformations of phosphorus in highly weathered subtropical soil following organic amendments. Plant Soil, 290, 333-342. http://dx.doi.org/10.1007/s11104-006-9165-5

Wu, J., Joergensen, R.G., Birgit Pommerening, Chaussod, R., \& Brookes, P. C. (1990). Measurement of Soil Microbial Biomass by Fumigation-Extraction-An automated Procedure. Soil Biol. Biochem, 22(8), 1167-1169. http://dx.doi.org/10.1016/0038-0717(90)90046-3

Zhu, Hanhua, Wu, Jinshui, Huang, Daoyou, Zhu, Qihong, Liu, Shoulong, Su, Yirong, Wei, Wenxue, Syers, J. Keith, \& Li, Yong. (2010). Improving fertility and productivity of a highly weathered upland soil in subtropical China by incorporating rice straw. Plant Soil, 331, 427-437. http://dx.doi.org/10.1007/s11104-009-0263-z

Table 1. Potato-Rape Total C, N, P and pH with treatments 2000-2008

\begin{tabular}{|c|c|c|c|c|}
\hline Treatments & Total carbon & Total Nitrogen & Total phosphorus & $\mathrm{pH}$ \\
\hline & \multicolumn{2}{|c|}{$\mathrm{g} \mathrm{kg}^{-1}$} & $\mathrm{mgkg}^{-1}$ & \\
\hline Fallow/nil fert. & $5.36 \mathrm{e}$ & $0.6766 \mathrm{e}$ & $0.308 \mathrm{~b}$ & $5.028 \mathrm{ba}$ \\
\hline Sweet potato-rape/nil fert & $5.78 \mathrm{~d}$ & $0.715 \mathrm{~d}$ & $0.312 \mathrm{~b}$ & $5.071 \mathrm{ba}$ \\
\hline Sweet potato-rape/NPK & $6.52 \mathrm{c}$ & $0.814 \mathrm{c}$ & $0.380 \mathrm{a}$ & $4.974 \mathrm{~b}$ \\
\hline Sweet Potato-rape/NP+straw & $7.18 \mathrm{a}$ & $0.882 \mathrm{a}$ & $0.351 \mathrm{a}$ & $5.126 \mathrm{a}$ \\
\hline Peanut-broadbean/NP+straw & $6.81 \mathrm{~b}$ & $0.856 \mathrm{ba}$ & $0.375 \mathrm{a}$ & $5.069 \mathrm{ba}$ \\
\hline Maize-barley/NK+marsh residue & $6.53 \mathrm{c}$ & $0.844 \mathrm{bc}$ & $0.375 \mathrm{a}$ & $5.007 \mathrm{~b}$ \\
\hline Maize-vegetable/NK+marsh residue & $6.66 \mathrm{cb}$ & $0.834 \mathrm{bc}$ & $0.398 \mathrm{a}$ & $4.985 \mathrm{~b}$ \\
\hline
\end{tabular}

Means with the same letters are not significantly different 
Table 2. Potato-Rape Microbial C, N, P and pH with treatments 2000-2008

\begin{tabular}{|c|c|c|c|}
\hline Treatments & Biomass. C & Biomass. N & Biomass. P \\
\hline & \multicolumn{3}{|c|}{$\mathrm{mg} \mathrm{kg}^{-1}$} \\
\hline Fallow/nil fert & $86.98 \mathrm{~d}$ & $14.924 \mathrm{~d}$ & $4.984 \mathrm{~b}$ \\
\hline Sweet potato-rape/nil fert. & $107.27 \mathrm{c}$ & $16.359 \mathrm{dc}$ & $4.969 \mathrm{~b}$ \\
\hline Sweet potato-rape/NPK & $125.13 \mathrm{~b}$ & $18.336 \mathrm{c}$ & $6.453 \mathrm{a}$ \\
\hline Sweet potato-rape/NPK+stalk & $132.66 \mathrm{a}(5.68 \%)$ & $23.956 \mathrm{a}(23.50 \%)$ & $7.351 \mathrm{a}$ \\
\hline Earthnut-broadbean/NPK+stalk & $129.81 \mathrm{ba}(3.61 \%)$ & $21.756 \mathrm{~b}(15.76 \%)$ & $7.387 \mathrm{a}$ \\
\hline
\end{tabular}

Means with the same letters are not significantly different; ( ) =\% difference with Sweet potato-rape/NPK treatment

Table 3. Potato fresh weight Yield 2000-2009 with year

\begin{tabular}{|c|c|c|}
\hline Year & Fresh Weight $\left(\right.$ tha $\left.^{-1}\right)$ & Percent difference from 2007 value (\%) \\
\hline 2000 & $4.38 \mathrm{a}$ & 65.07 \\
\hline 2001 & $3.43 \mathrm{cb}$ & 55.39 \\
\hline 2002 & $3.88 \mathrm{~b}$ & 60.57 \\
\hline 2003 & $3.76 \mathrm{~b}$ & 59.31 \\
\hline 2004 & $2.85 \mathrm{~d}$ & 46.32 \\
\hline 2005 & $3.04 \mathrm{~cd}$ & 49.67 \\
\hline 2006 & $3.27 \mathrm{~cd}$ & 53.21 \\
\hline 2007 & $1.53 \mathrm{f}$ & - \\
\hline 2008 & $1.82 \mathrm{fe}$ & 15.93 \\
\hline 2009 & $2.08 \mathrm{e}$ & 26.44 \\
\hline
\end{tabular}

Means with the same letters are not significantly different

Table 4. Threshold Limit for Sweet Potato Ultisol Fields in Subtropical China Region

\begin{tabular}{|c|c|c|c|}
\hline Data set & High & Medium & Low \\
\hline Total carbon $\left(\mathrm{g} \mathrm{kg}^{-1}\right)$ & $>\quad 6.5$ & $5.5-6.5$ & $<5.5$ \\
\hline Total Nitrogen $\left(\mathrm{g} \mathrm{kg}^{-1}\right)$ & $>\quad 0.82$ & $0.7-0.82$ & $<0.7$ \\
\hline Total phosphorus ( $\mathrm{mg} \mathrm{kg}^{-1}$ ) & $>0.38$ & $0.34-0.38$ & $<0.34$ \\
\hline Biomass carbon $\left(\mathrm{mg} \mathrm{kg}^{-1}\right)$ & $>\quad 120$ & $110-120$ & $<110$ \\
\hline Biomass Nitrogen $\left(\mathrm{mg} \mathrm{kg}^{-1}\right)$ & 22 & $18-22$ & $<18$ \\
\hline Soil pH & $<5.07$ & $5.01-5.07$ & $<5.01$ \\
\hline Biomass phosphorus ( $\mathrm{mg} \mathrm{kg}^{-1}$ ) & 7.0 & $5.5-7.0$ & $<5.5$ \\
\hline Fresh Potato yield $\left(\right.$ tha $\left.^{-1}\right)$ & 4.0 & $3.2-4.0$ & $<3.2$ \\
\hline
\end{tabular}

\section{Total carbon (gkg-1)}

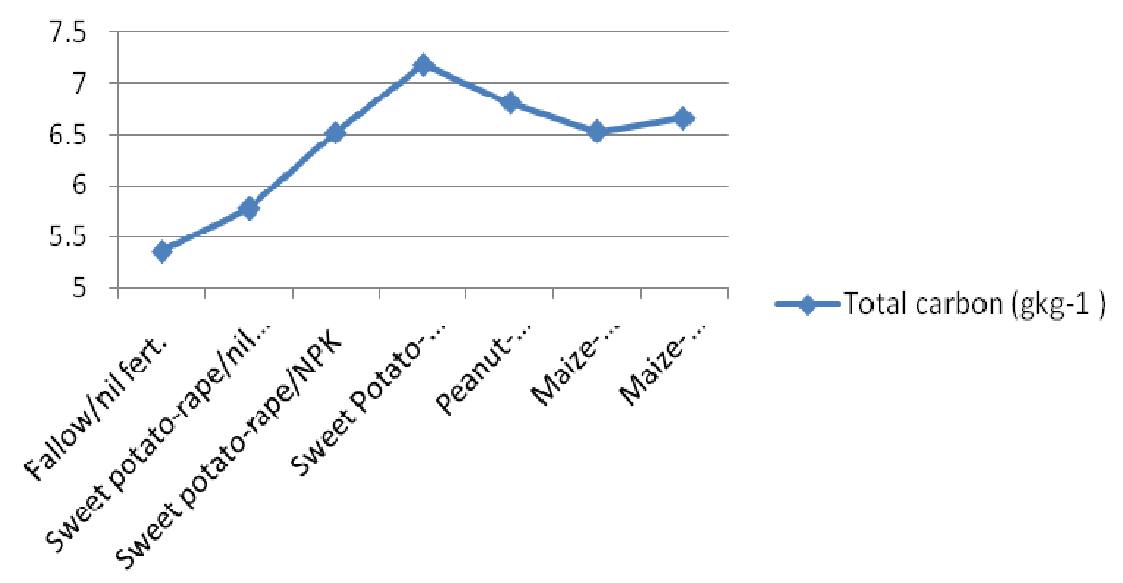

Figure 1. Sweet Potato Field Total Carbon 2000-2009 


\section{Total Nitrogen (gkg-1)}

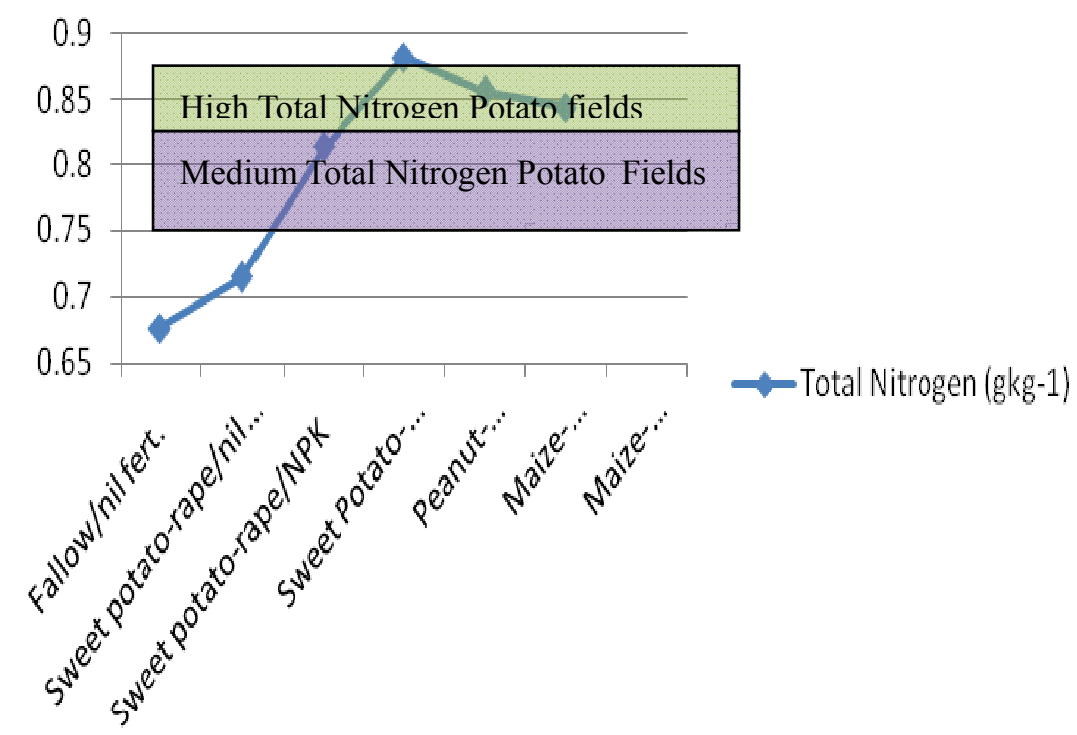

Figure 2. Sweet Potato Field Total Nitrogen 2000-2009

\section{Total phosphorus (mgkg-1)}

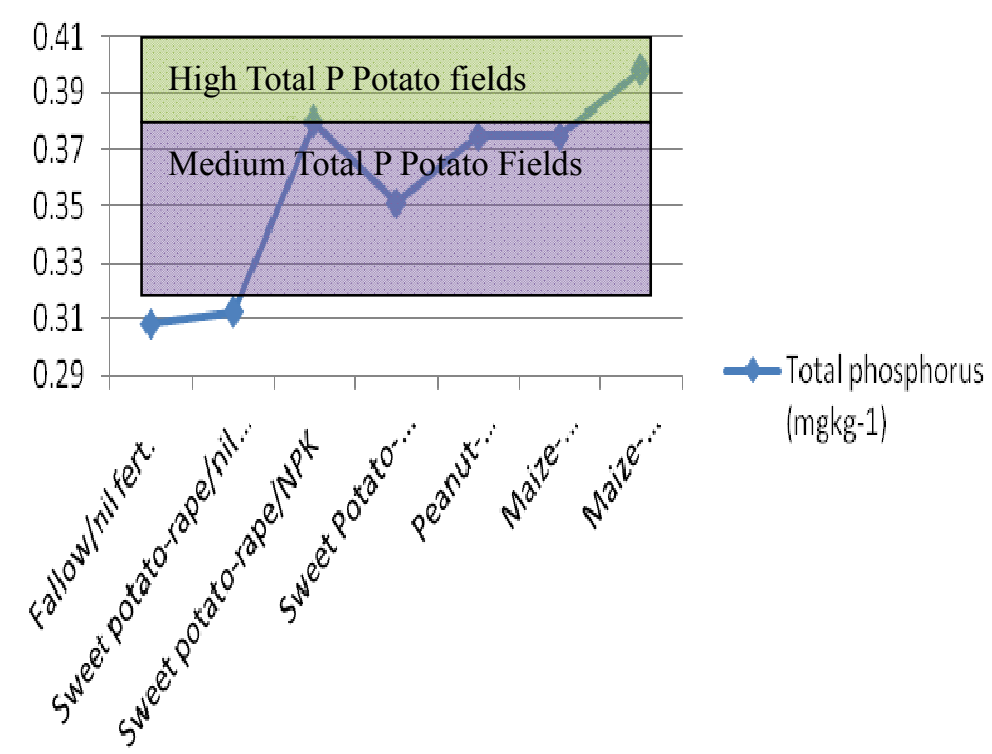

Figure 3. Sweet Potato Fields Total Phosphorus 2000-2009 
$\mathrm{pH}$

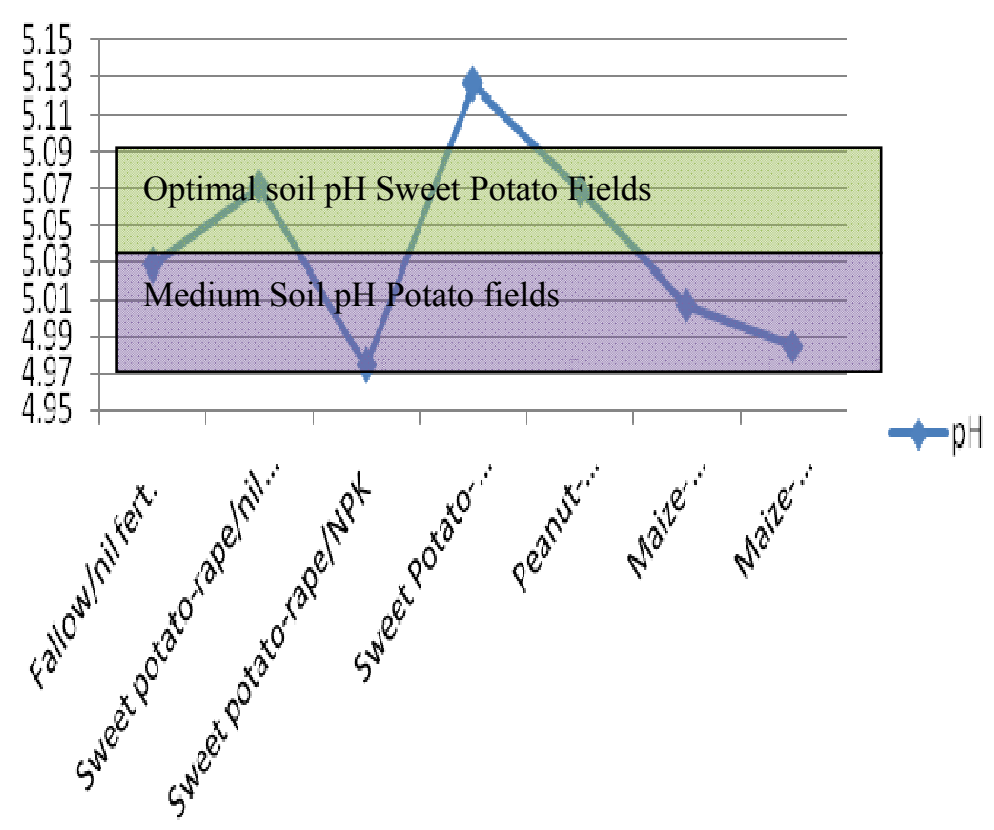

Figure 4. Sweet Potato Fields Soil pH 2000-2009

\section{Biomass. C(mgkg-1)}

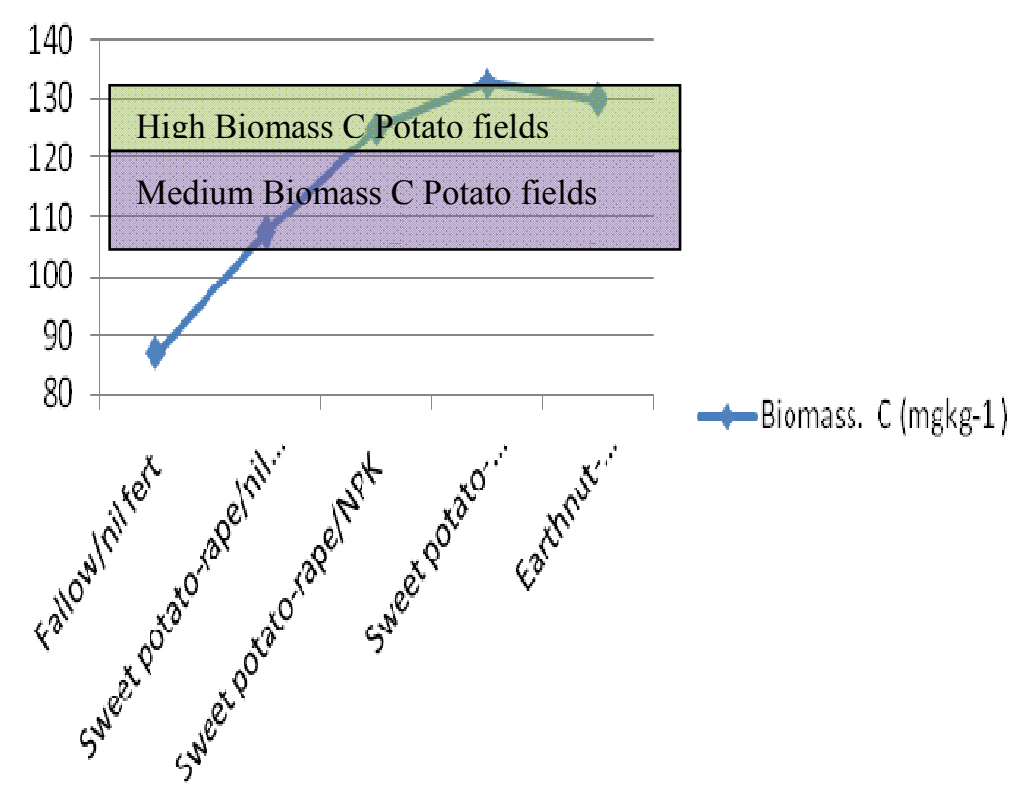

Figure 5. Sweet Potato Fields Biomass Carbon 


\section{Biomass. N (mgkg-1)}

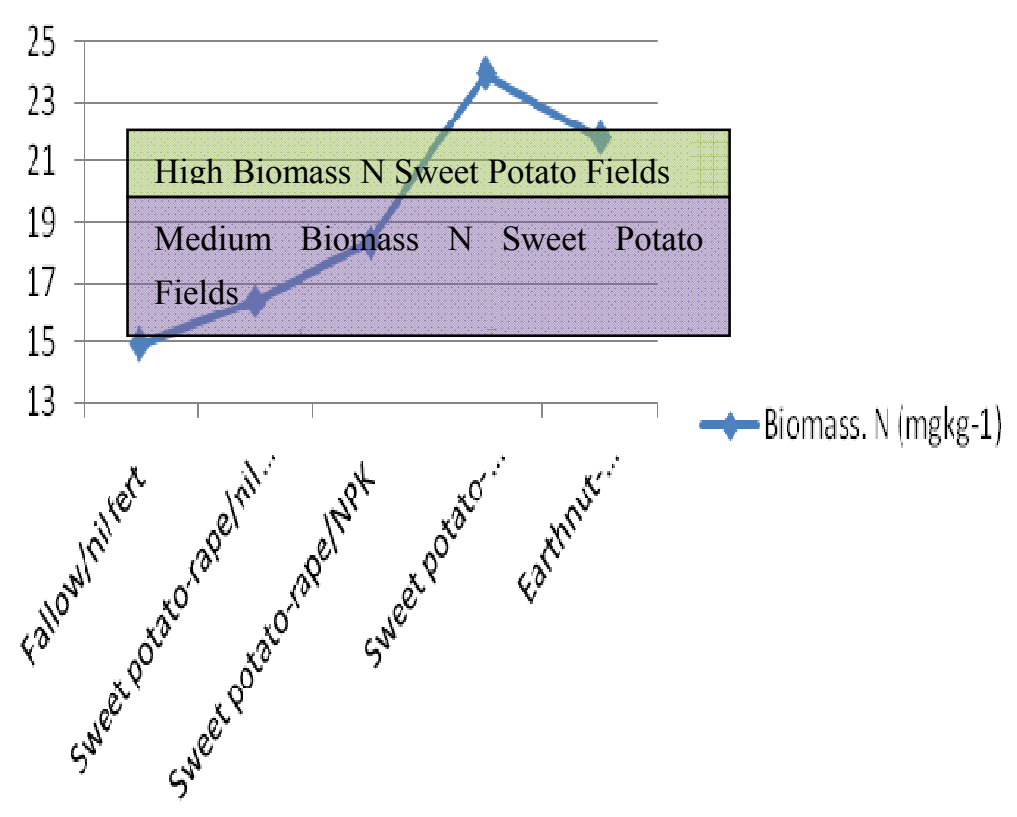

Figure 6. Sweet Potato Fields Biomass Nitrogen

\section{Biomass. P(mgkg-1)}

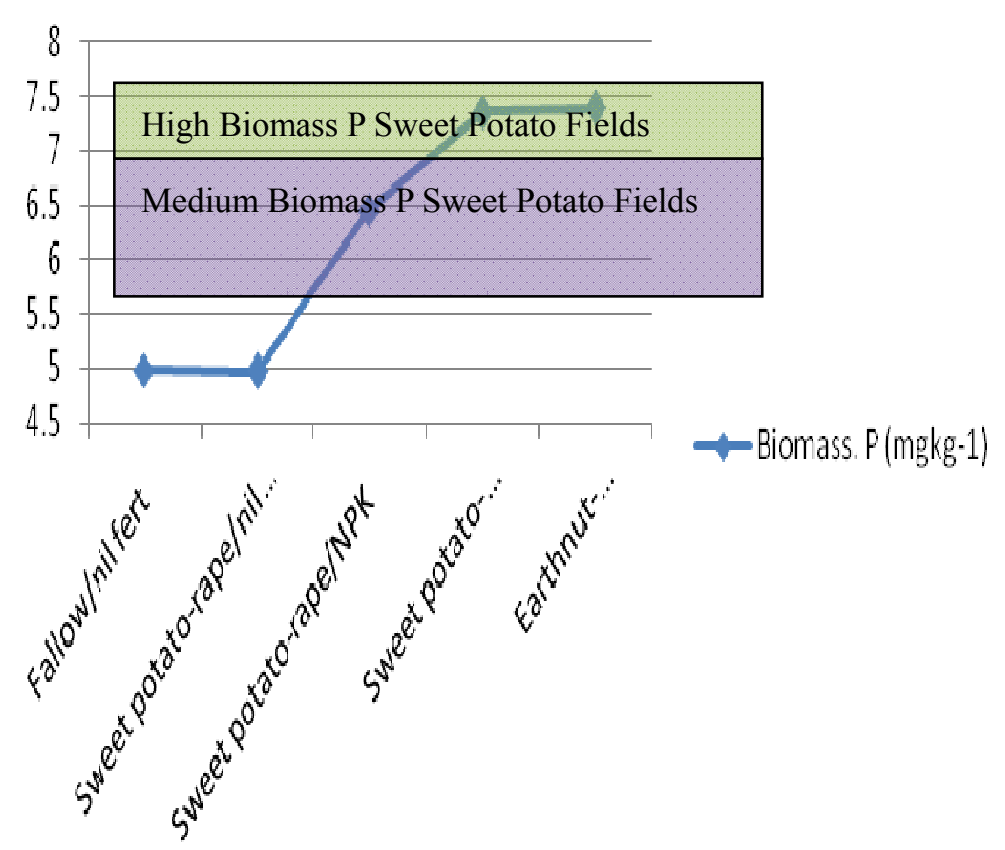

Figure 7. Sweet Potato Fields Biomass Phosphorus 


\section{Fresh Weight (tha-1)}

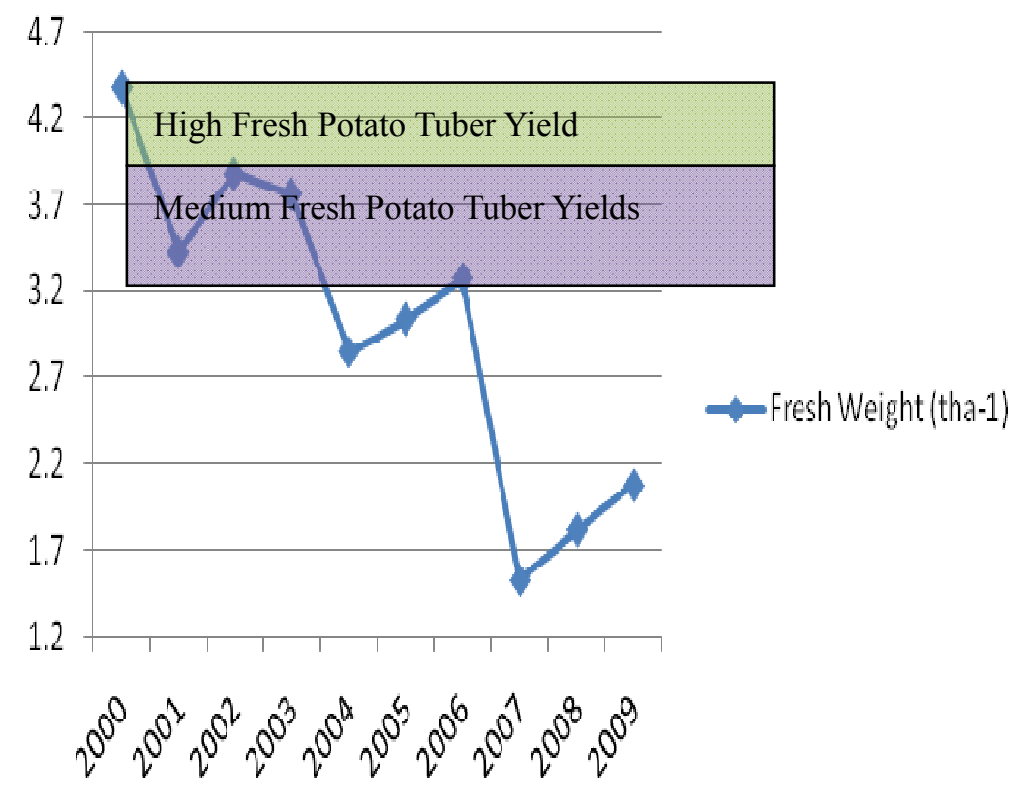

Figure 8. Fresh Sweet Potato Yield 2000-2009 